\title{
Mechanical Behavior and Fracture Properties of NiAl Intermetallic Alloy with Different Copper Contents
}

\author{
Tao-Hsing Chen * and Jian-Hong Wu \\ Department of Mechanical Engineering, National Kaohsiung University of Applied Sciences, \\ Kaohisung 807, Taiwan; stars0619@gmail.com \\ * Correspondence: thchen@cc.kuas.edu.tw; Tel.: +8867-3814-5265-330; Fax: +8867-3831-373 \\ Academic Editor: Chien-Hung Liu \\ Received: 21 December 2015; Accepted: 15 February 2016; Published: 2 March 2016
}

\begin{abstract}
The deformation behavior and fracture characteristics of $\mathrm{NiAl}$ intermetallic alloy containing $5 \sim 7 \mathrm{at} \% \mathrm{Cu}$ are investigated at room temperature under strain rates ranging from $1 \times 10^{-3}$ to $5 \times 10^{3} \mathrm{~s}^{-1}$. It is shown that the copper contents and strain rate both have a significant effect on the mechanical behavior of the NiAl alloy. Specifically, the flow stress increases with an increasing copper content and strain rate. Moreover, the ductility also improves as the copper content increases. The change in the mechanical response and fracture behavior of the NiAl alloy given a higher copper content is thought to be the result of the precipitation of $\beta$-phase $(\mathrm{Ni}, \mathrm{Cu}) \mathrm{Al}$ and $\gamma^{\prime}$-phase $(\mathrm{Ni}, \mathrm{Cu})_{3} \mathrm{Al}$ in the NiAl matrix.
\end{abstract}

Keywords: intermetallic; $\mathrm{NiAl}$ alloy; strain rate effect; fracture properties; precipitate

\section{Introduction}

$\mathrm{NiAl}$ intermetallic alloy has many favorable properties, including a high mechanical strength, a low density, a high melting point and a good oxidation resistance at high temperature environment [1-5]. As a result, it is an ideal material for structural applications subject to corrosive and oxidant environments [6-8]. However, under room temperature conditions, $\mathrm{NiAl}$ has a poor ductility. Meanwhile, NiAl intermetallic alloy has poor creep resistance and strength at elevated temperature [9]. These are the major drawbacks to its engineering use. Several attempts have been made to improve the room temperature ductility of NiAl intermetallics alloy through the addition of alloying elements, reduction of grain size and other solidification processing [10,11]. Furthermore, it has been shown that the addition of elements such as $\mathrm{Cu}, \mathrm{Co}, \mathrm{Mo}$, Ti and Fe is particularly beneficial in improving the mechanical properties of $\mathrm{NiAl}$ intermetallic alloy [12-17]. Among these additions, $\mathrm{Cu}$ is an excellent addition to improve the room ductility of NiAl intermetallic alloy [18]. Some studies reported that the improvement of the NiAl alloy's room temperature ductility are governed by the presence of $\beta$-phase $(\mathrm{Ni}, \mathrm{Cu}) \mathrm{Al}$ and $\gamma^{\prime}$-phase $(\mathrm{Ni}, \mathrm{Cu})_{3} \mathrm{Al}[19,20]$. Furthermore, there are many studies in the literature that have reported the quasi-static loading condition (under low strain rate) performance of $\mathrm{NiAl}$ intermetallic alloy [21-23]. However, previous studies have not investigated the effect of the high strain rate on the mechanical and fracture properties of $\mathrm{NiAl}$ intermetallic alloy. However, the strain rate has a critical effect on the mechanical integrity of structural components; under high strain rate loading, adiabatic shear bands are readily formed which serve as preferential sites of crack initiation [24-26]. Accordingly, the present study investigates the mechanical behavior of $\mathrm{NiAl}$ intermetallic alloy containing $5 \sim 7 \mathrm{at} \% \mathrm{Cu}$ at a temperature of $25^{\circ} \mathrm{C}$ and strain rates ranging from $10^{-3}$ to $5 \times 10^{3} \mathrm{~s}^{-1}$. The microstructural evolution of the various $\mathrm{NiAlCu}$ samples is observed using scanning electron microscopy (SEM) and optical microscopy (OM). 


\section{Material Preparation and Experimental Procedure}

The NiAlCu intermetallic alloys were prepared in a vacuum arc melted furnace under an Ar atmosphere using appropriate quantities of high-purity $(99.99 \%) \mathrm{Ni}, \mathrm{Al}$ and $\mathrm{Cu}$ powders (support by Golden Optoelectronic Co. Ltd., New Taipei City, Taiwan). Each ingot was inverted and remelted three times in order to ensure compositional homogeneity. Finally, the ingots were heat treated at 1473 $\mathrm{K}$ for $24 \mathrm{~h}$. The cylindrical specimens with a length of $5 \pm 0.1 \mathrm{~mm}$ and a diameter of $5.1 \mathrm{~mm}$ were machined from the as-cast ingots and finished to a final diameter of $5 \pm 0.1 \mathrm{~mm}$ via a center-grinding process. The mechanical properties of the various ingots were evaluated at room temperature by means of quasi-static and dynamic tests. In the quasi-static tests, the specimens were deformed at strain rates of $10^{-3}, 10^{-2}$ and $10^{-1} \mathrm{~s}^{-1}$, respectively, using a material testing system (MTS 810 series; MTS Systems Corporation, Minneapolis, MN, USA). The dynamic tests were performed at strain rates of $3 \times 10^{3} \mathrm{~s}^{-1}, 4 \times 10^{3} \mathrm{~s}^{-1}$ and $5 \times 10^{3} \mathrm{~s}^{-1}$ using a split-Hopkinson Pressure Bar (SHPB) system (Long Win Science and Technology Corporation, Taoyuan, Taiwan). When performing the dynamic tests, the specimens were sandwiched between the incident bar and the transmitter bar of the SHPB system, and the incident bar was then impacted by a striker bar fired by a gas gun. The stress-strain curves of the impacted specimens were obtained by measuring the stress waves propagating through the incident and transmitter bar by means of strain gauges attached to the midpoint position of each bar. The microstructural characteristics of the impacted specimens were examined by SEM (JEOL-6330TF; JEOL Ltd., Akishima, Japan) and OM (Carl Zeiss NEOPHOT 2; Carl Zeiss, Now York, NY, USA). In addition, the constituent phase of the various specimens was identified by X-raydiffraction (Philips X'Pert-MRD X-ray diffractometer; Spectris plc, Almelo, The Netherlands). Finally, the microhardness of each specimen was measured using a Buehler MHT2 microhardness tester (Buehler Company, Lake Bluff, IL, USA) with Vickers diamond pyramidindenter (Buehler Company, Lake Bluff, IL, USA), and a load of loads of $300 \mathrm{~g}$ and time of $15 \mathrm{~s}$ on the test materials. For each specimen, at least 5 measurements were executed.

\section{Results and Discussion}

\subsection{Stress-Strain Response}

Figure $1 \mathrm{a}-\mathrm{c}$ show the stress-strain curves of the NiAl alloys with 5 at $\%, 6$ at $\%$ and 7 at $\% \mathrm{Cu}$, respectively. It is seen that for all specimens, the flow stress varies with both the strain rate and the $\mathrm{Cu}$ content. For a given $\mathrm{Cu}$ content, the flow stress increases with increasing strain rate. Moreover, for a given strain rate, the maximum stress increases with increasing $\mathrm{Cu}$ content. Overall, it is seen that the strain rate has a greater effect on the flow stress than the $\mathrm{Cu}$ content. In addition, it is noted that specimen fracture occurs more readily in the specimens with a lower $\mathrm{Cu}$ content. For the specimens containing $5 \% \mathrm{Cu}$, the fracture strain decreases with increasing true strain (Figure 1a). However, as the $\mathrm{Cu}$ content is increased to $6 \%$, the fracture strain increases (Figure 1b). For the maximum considered $\mathrm{Cu}$ content of $7 \%$, fracture occurs only at the highest strain rate of $5 \times 10^{3} \mathrm{~s}^{-1}$. In other words, both the strengthening properties and the ductility of the NiAl specimens increase with an increasing $\mathrm{Cu}$ addition. Figure $1 \mathrm{~d}$ compares the unalloyed $\mathrm{NiAl}$ alloy with different $\mathrm{Cu}$ contents under strain rate of $10^{-1} \mathrm{~s}^{-1}$ and $25^{\circ} \mathrm{C}$. It can be seen that the stress of unalloyed $\mathrm{NiAl}$ (binary) is the lowest. 


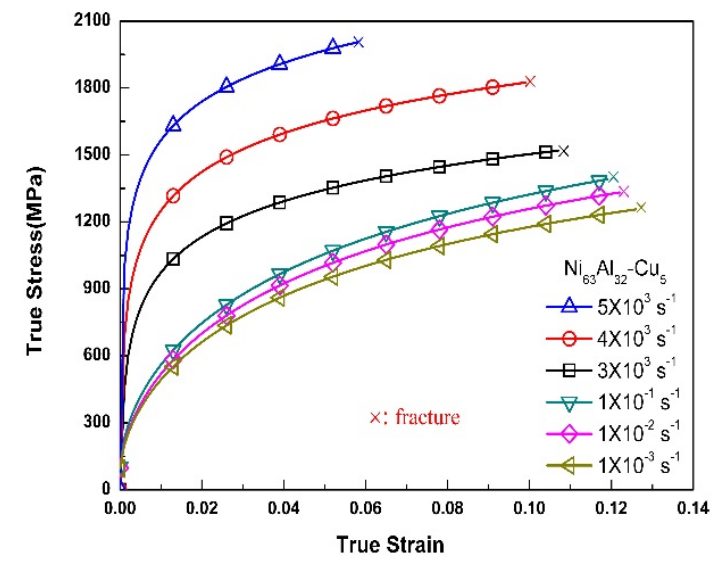

(a)

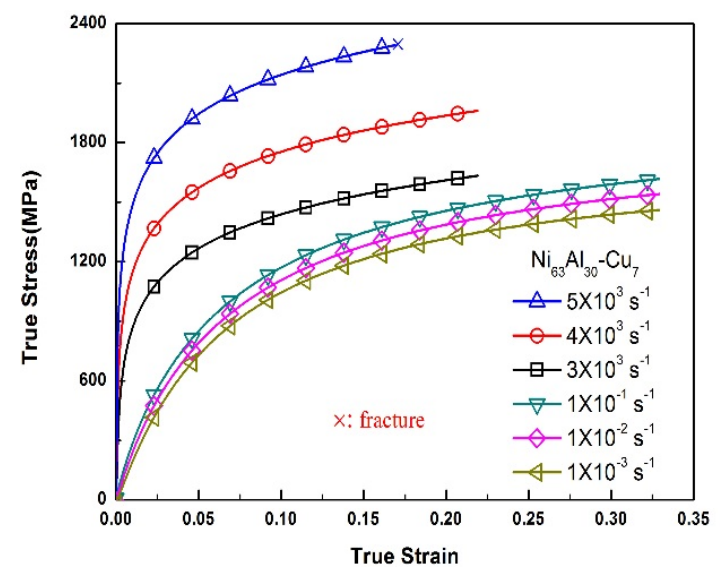

(c)

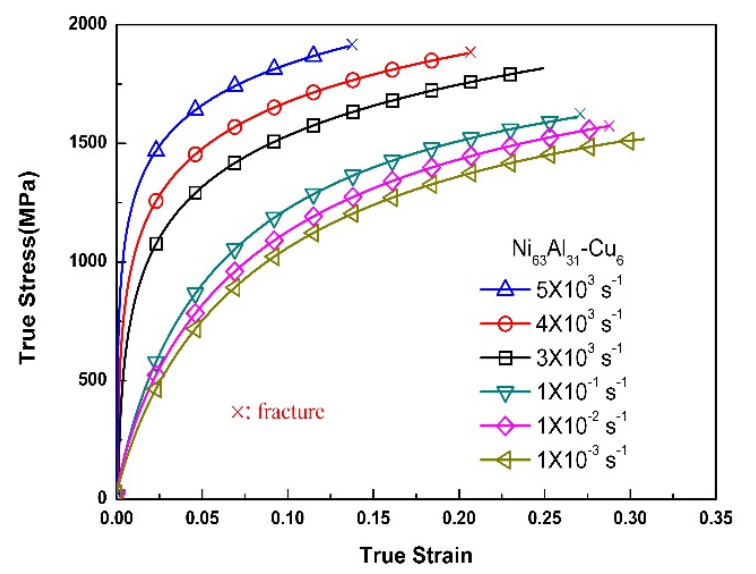

(b)

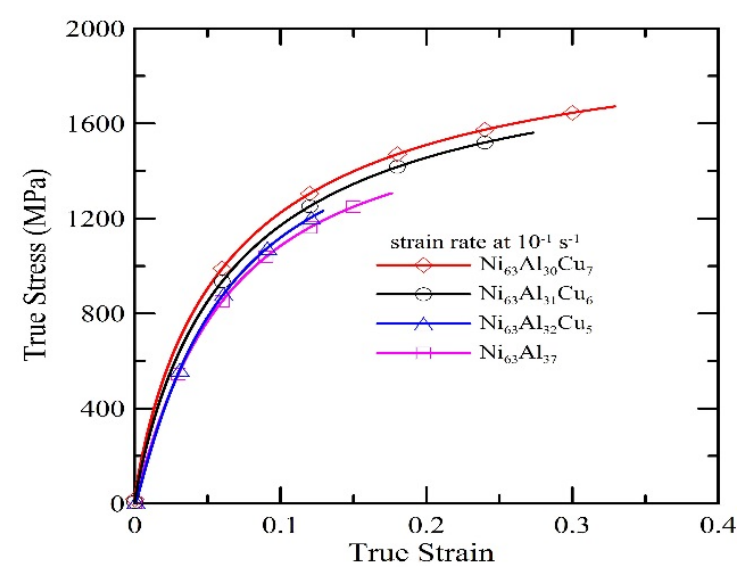

(d)

Figure 1. Stress-strain curves of $\mathrm{NiAl}$ intermetallic alloys deformed at strain rates of $10^{-3}-5 \times 10^{3} \mathrm{~s}^{-1}$ :

(a) $\mathrm{Ni}_{63} \mathrm{Al}_{32} \mathrm{Cu}_{5} ;$ (b) $\mathrm{Ni}_{63} \mathrm{Al}_{32} \mathrm{Cu}_{6}$; (c) $\mathrm{Ni}_{63} \mathrm{Al}_{32} \mathrm{Cu}_{7}$ and (d) comparison of four NiAl alloy.

The stress-strain curves presented in Figure 1 show that the specimens deformed at different strain rates have a different work hardening response. In general, the stress-strain response of engineering metals and alloys can be described by the power law:

$$
\sigma=A+B \varepsilon^{n}
$$

where $A$ is the yield strength, $B$ is the material constant and $n$ is the work hardening coefficient.

Table 1 presents the results obtained for $A, B$ and $n$ for the present NiAlCu specimens by curve-fitting the experimental data in Figure 1. It is seen that for a constant $\mathrm{Cu}$ content, the yield strength, material constant and work hardening coefficient all increase with increasing strain rate. Moreover, it is noted that the material constant $(B)$ has a higher value under quasi-static loading than under dynamic loading. Thus, it is inferred that the dislocation density and multiplication rate increase at higher strain rates and give rise to an enhanced flow resistance. For a given strain rate, the yield strength, material constant and work hardening coefficient all increase with increasing $\mathrm{Cu}$ addition. In other words, a higher $\mathrm{Cu}$ content not only increases the flow stress, but also the fracture strain. Table 2 shows the hardness values of the different NiAlCu specimens. It is seen that the hardness increases with both an increasing strain rate and an increasing $\mathrm{Cu}$ content. 
Table 1. Mechanical properties of NiAlCu intermetallic alloys deformed at room temperature $\left(25^{\circ} \mathrm{C}\right)$ under strain rates of $10^{-3}-5 \times 10^{3} \mathrm{~s}^{-1}$.

\begin{tabular}{|c|c|c|c|c|}
\hline Alloy & Strain Rate $\left(\mathrm{s}^{-1}\right)$ & $\begin{array}{c}\text { Yielding Strength, } \\
A(\mathrm{MPa})\end{array}$ & $\begin{array}{c}\text { Material Constant, } \\
\text { B (MPa) }\end{array}$ & $\begin{array}{l}\text { Work Hardening } \\
\text { Coefficient, } n\end{array}$ \\
\hline \multirow{6}{*}{$\mathrm{Ni}_{63} \mathrm{Al}_{32} \mathrm{Cu}_{5}$} & $10^{-3}$ & 449.3 & 3056.6 & 0.62 \\
\hline & $10^{-2}$ & 475.9 & 3410.9 & 0.64 \\
\hline & $10^{-1}$ & 520.67 & 3647.8 & 0.65 \\
\hline & $3 \times 10^{3}$ & 925.8 & 2257.9 & 0.68 \\
\hline & $4 \times 10^{3}$ & 1205.86 & 2626.8 & 0.72 \\
\hline & $5 \times 10^{3}$ & 1562.66 & 2918.2 & 0.77 \\
\hline \multirow{6}{*}{$\mathrm{Ni}_{63} \mathrm{Al}_{32} \mathrm{Cu}_{6}$} & $10^{-3}$ & 571.3 & 2072.8 & 0.63 \\
\hline & $10^{-2}$ & 656.57 & 2203.3 & 0.66 \\
\hline & $10^{-1}$ & 771.74 & 2162.3 & 0.67 \\
\hline & $3 \times 10^{3}$ & 1073.07 & 1802.4 & 0.7 \\
\hline & $4 \times 10^{3}$ & 1236.94 & 1884.8 & 0.73 \\
\hline & $5 \times 10^{3}$ & 1331.2 & 2171.2 & 0.78 \\
\hline \multirow{6}{*}{$\mathrm{Ni}_{63} \mathrm{Al}_{32} \mathrm{Cu}_{7}$} & $10^{-3}$ & 695.5 & 1628.0 & 0.65 \\
\hline & $10^{-2}$ & 750.7 & 1697.4 & 0.68 \\
\hline & $10^{-1}$ & 809.0 & 1744.0 & 0.70 \\
\hline & $3 \times 10^{3}$ & 1048.6 & 1563.0 & 0.71 \\
\hline & $4 \times 10^{3}$ & 1289.6 & 1661.6 & 0.75 \\
\hline & $5 \times 10^{3}$ & 1676.5 & 2190.0 & 0.80 \\
\hline
\end{tabular}

Table 2. Hardness values of NiAlCu intermetallic alloys.

\begin{tabular}{cc}
\hline Alloy & Average Hardness Value \\
\hline $\mathrm{Ni}_{63} \mathrm{Al}_{32}-\mathrm{Cu}_{5}$ & $301.16(\mathrm{Hv})$ \\
$\mathrm{Ni}_{63} \mathrm{Al}_{31}-\mathrm{Cu}_{6}$ & $325.63(\mathrm{Hv})$ \\
$\mathrm{Ni}_{63} \mathrm{Al}_{30}-\mathrm{Cu}_{7}$ & $353.9(\mathrm{Hv})$ \\
\hline
\end{tabular}

In general, the precipitation of secondary phase $\gamma^{\prime}$ from the $\beta$-phase results in alloys with a greater hardness and a reduced susceptibility to brittle fracture [27]. Furthermore, lattice defects in the intermetallic structure may increase or decrease the intermetallic hardness depending on lattice distortion [28]. In the present study, a notable strengthening of the binary NiAl intermetallic alloy system occurs as the $\mathrm{Cu}$ content is increased. Hence, it is inferred that $\mathrm{Cu}$ addition results in major lattice distortion due to substructure defects, and leads to a greater microhardness as a result.

\subsection{Strain Rate Effect}

The strain rate sensitivity of the NiAlCu alloy specimens can be calculated from the experimental stress-strain curves presented in Figure 1 in accordance with [29].

$$
\beta=(\partial \sigma / \partial \ln \dot{\varepsilon})=\frac{\sigma_{2}-\sigma_{1}}{\ln \left(\dot{\varepsilon}_{2}-\dot{\varepsilon}_{1}\right)}
$$

Figure 2a-c present the corresponding results obtained for the strain rate sensitivity of the NiAl alloys with $\mathrm{Cu}$ additions of $5 \mathrm{at} \%, 6$ at $\%$ and 7 at $\%$, respectively. It is observed that the strain rate sensitivity increases with increasing strain rate, strain and $\mathrm{Cu}$ content [5]. It is thought that the greater strain rate sensitivity is the result of a rapid multiplication of dislocations [30-32] in the deformed microstructure under an increased strain rate and the blocking of these dislocations by secondary phases precipitated under higher levels of $\mathrm{Cu}$ addition. 


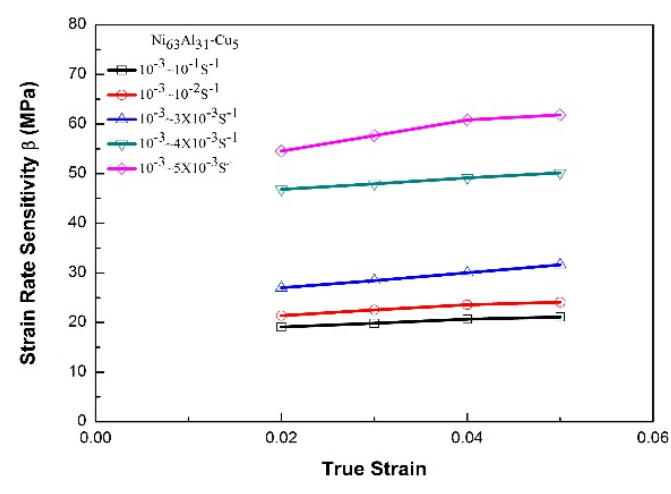

(a)

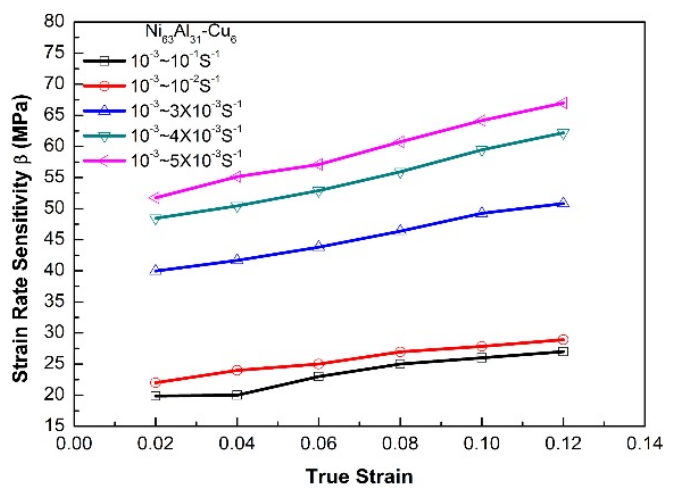

(b)

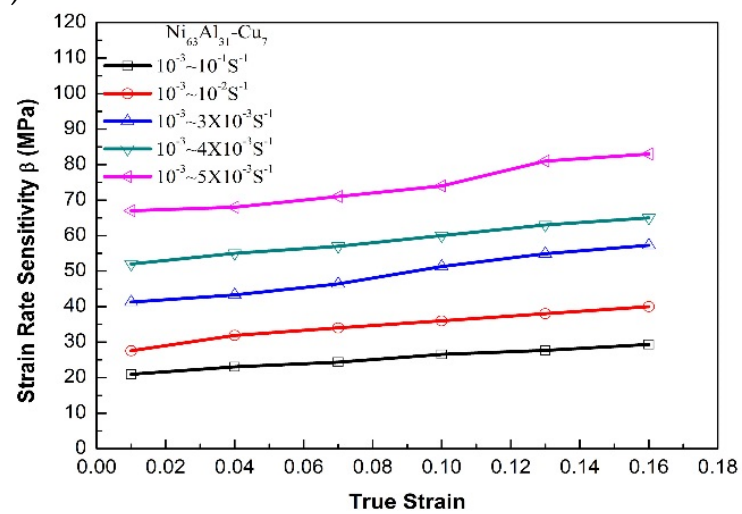

(c)

Figure 2. Variation of strain rate sensitivity with true strain as function of strain rate for different $\mathrm{NiAl}$ intermetallic alloys: (a) $\mathrm{Ni}_{63} \mathrm{Al}_{32} \mathrm{Cu}_{5}$; (b) $\mathrm{Ni}_{63} \mathrm{Al}_{32} \mathrm{Cu}_{6}$ and (c) $\mathrm{Ni}_{63} \mathrm{Al}_{32} \mathrm{Cu}_{7}$.

\subsection{Microstructural Observations and Fracture Analysis}

Figure 3a-c present OM micrographs of the as-cast NiAl alloys with different levels of $\mathrm{Cu}$ addition. It is seen that the matrix contains a random distribution of annealing twins and precipitates in every case. Moreover, the number of precipitates increases with an increasing $\mathrm{Cu}$ content. (Figure $4 \mathrm{a}-\mathrm{C}$ present the X-ray diffraction (XRD) analysis results for the NiAl alloys with different levels of $\mathrm{Cu}$ addition. Moreover, it is seen that for each specimen, the peak value of the $\beta$-phase $(\mathrm{Ni}, \mathrm{Cu}) \mathrm{Al}$ is greater than that of the $\gamma^{\prime}$-phase $(\mathrm{Ni}, \mathrm{Cu})_{3} \mathrm{Al}$. In general, the results presented in Figures 3 and 4 suggest that the enhanced flow stress and strain rate sensitivity of the NiAlCu alloy observed at higher strain rates and levels of $\mathrm{Cu}$ addition are a result of the increased precipitation of $\beta$-phase $(\mathrm{Ni}, \mathrm{Cu}) \mathrm{Al}$ and $\gamma^{\prime}$-phase $(\mathrm{Ni}, \mathrm{Cu})_{3} \mathrm{Al}$.

Figure $5 \mathrm{a}-\mathrm{c}$ present SEM micrographs of the fracture surfaces of the NiAl alloy containing $5 \%$ $\mathrm{Cu}$ following impact testing at strain rates of $3 \times 10^{3} \mathrm{~s}^{-1}, 4 \times 10^{3} \mathrm{~s}^{-1}$ and $5 \times 10^{3} \mathrm{~s}^{-1}$, respectively. The images show that the specimens fracture in a brittle failure mode. Furthermore, the number of cleavage surfaces increases with an increasing strain rate. However, for the specimen with a higher $\mathrm{Cu}$ content of $6 \%$, the number of cleavage surfaces is reduced and melted knobby structures are observed (Figure $5 \mathrm{~d}, \mathrm{e}$ ). The presence of the knobby features suggests that the local temperature exceeded the melting point of $\mathrm{NiAl}$ alloy during deformation. Furthermore, only the specimens tested under strain rates of $4 \times 10^{3} \mathrm{~s}^{-1}$ and $5 \times 10^{3} \mathrm{~s}^{-1}$ failed, which suggests that a higher $\mathrm{Cu}$ content increases the ductility of NiAl alloy. For the highest considered $\mathrm{Cu}$ content of 7 at $\%$, the fracture surface contains a greater number of knobby features (Figure 5f). Moreover, only the specimen tested at the maximum strain rate of $5 \times 10^{3} \mathrm{~s}^{-1}$ failed. Consequently, the effect of $\mathrm{Cu}$ addition in improving the ductility of $\mathrm{NiAl}$ alloy is further confirmed. 


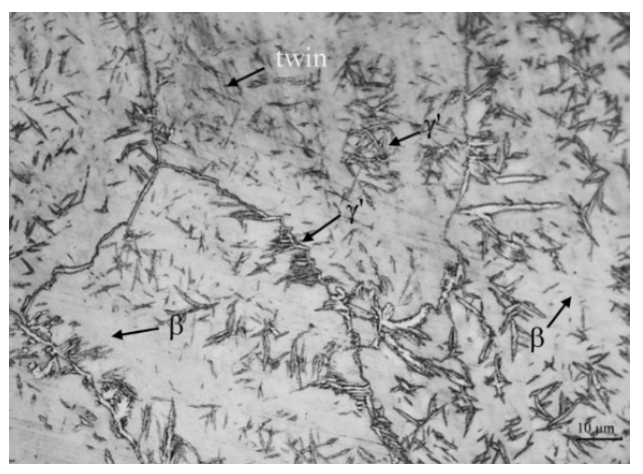

(a)

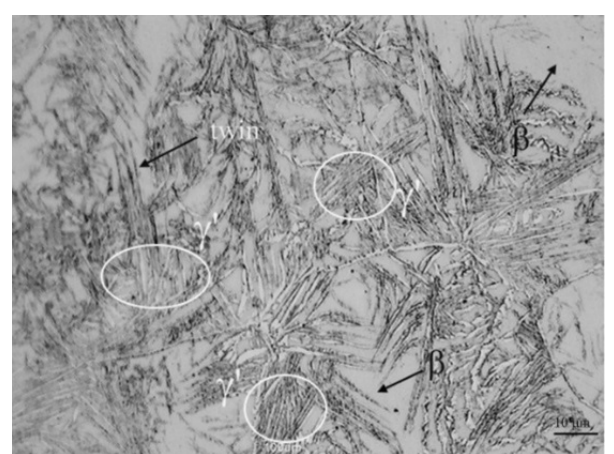

(b)

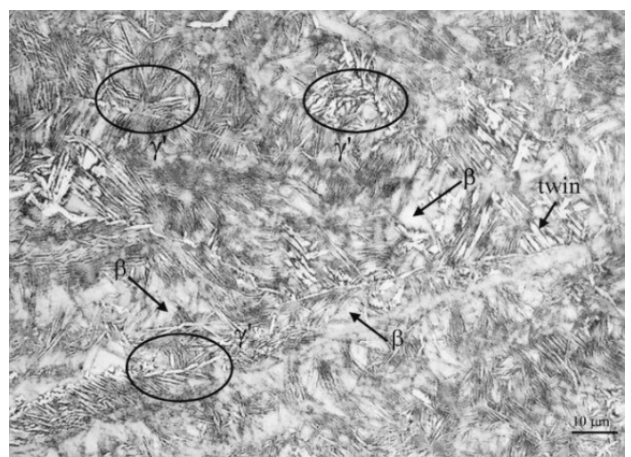

(c)

Figure 3. Optical micrographs of as-cast $\mathrm{NiAl}$ intermetallic alloys: (a) $\mathrm{Ni}_{63} \mathrm{Al}_{32} \mathrm{Cu}_{5}$; (b) $\mathrm{Ni}_{63} \mathrm{Al}_{32} \mathrm{Cu}_{6}$; and (c) $\mathrm{Ni}_{63} \mathrm{Al}_{32} \mathrm{Cu}_{7}$.

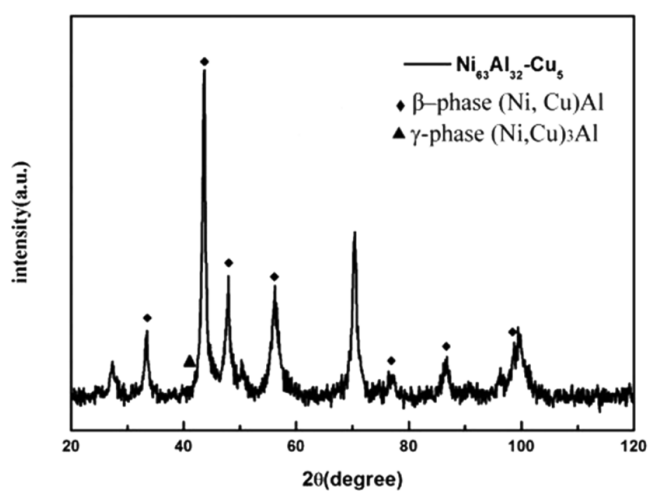

(a)

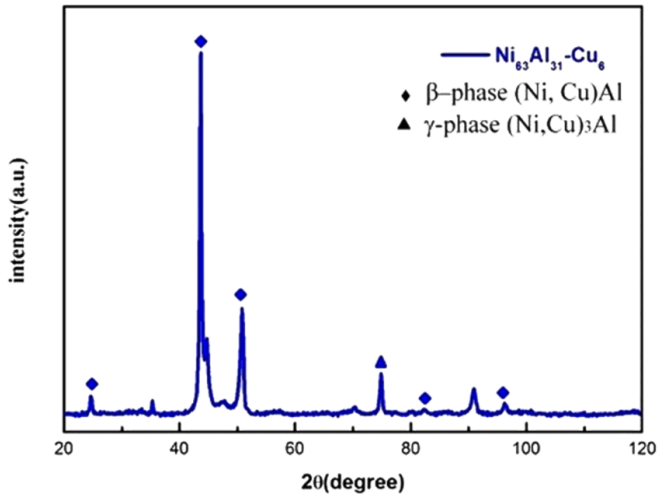

(b)

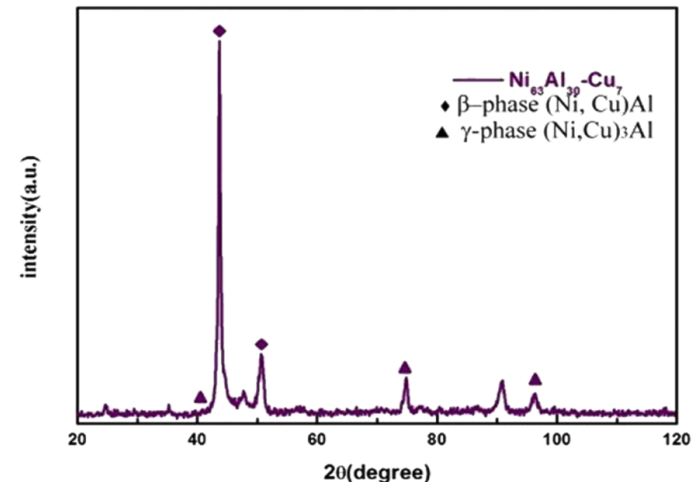

(c)

Figure 4. $\mathrm{X}$-ray diffraction (XRD) analysis results for as-cast $\mathrm{NiAl}$ intermetallic alloys: (a) $\mathrm{Ni}_{63} \mathrm{Al}_{32} \mathrm{Cu}_{5}$; (b) $\mathrm{Ni}_{63} \mathrm{Al}_{32} \mathrm{Cu}_{6}$; and (c) $\mathrm{Ni}_{63} \mathrm{Al}_{32} \mathrm{Cu}_{7}$. 


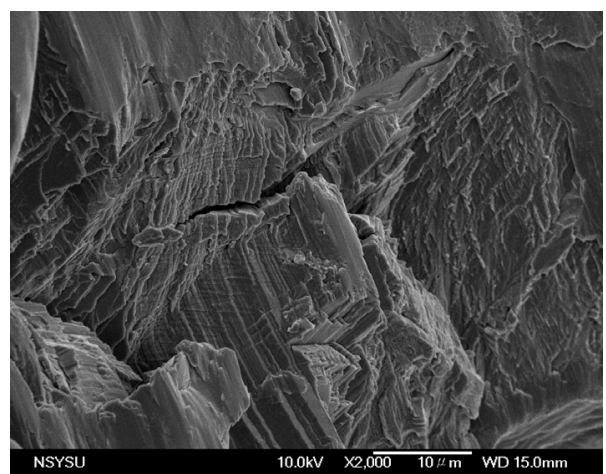

(a)

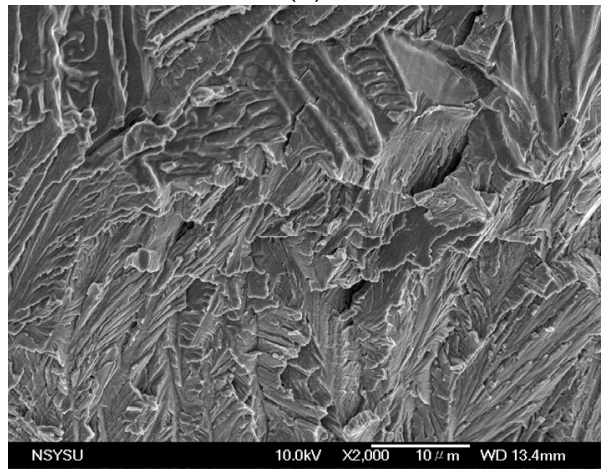

(c)

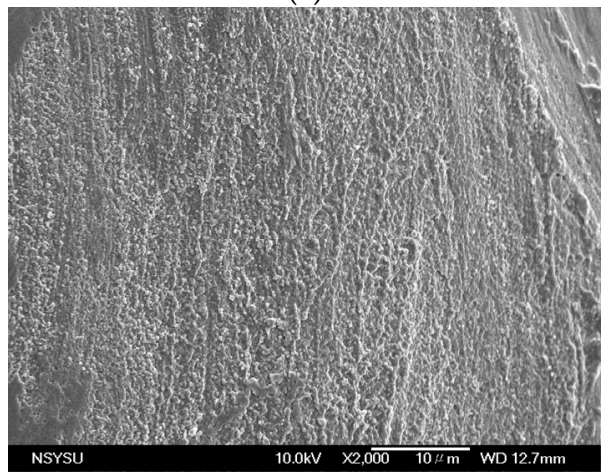

(e)

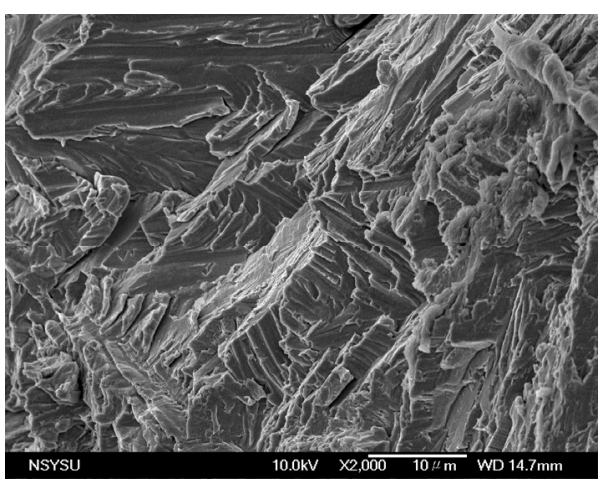

(b)

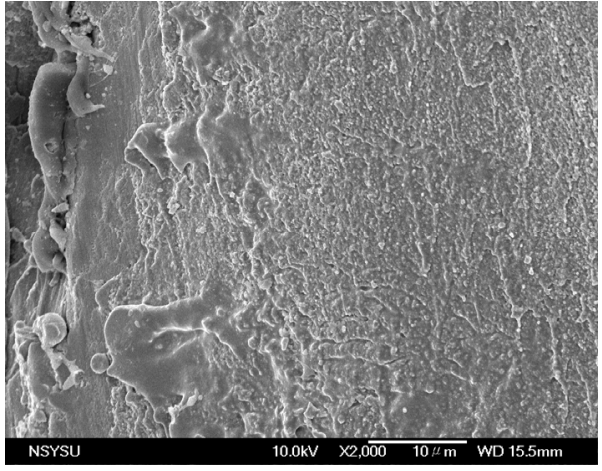

(d)

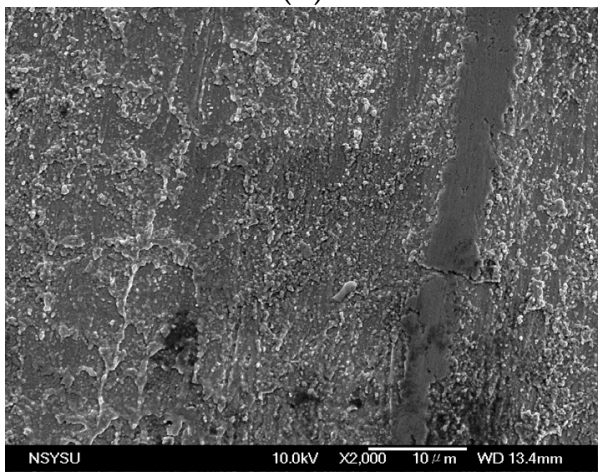

(f)

Figure 5. Fracture features of impacted $\mathrm{NiAl}$ intermetallic alloys: (a) $3 \times 10^{3} \mathrm{~s}^{-1}$; (b) $4 \times 10^{3} \mathrm{~s}^{-1}$; (c) $5 \times 10^{3} \mathrm{~s}^{-1} ; \mathrm{Ni}_{63} \mathrm{Al}_{32} \mathrm{Cu}_{5} ;$ (d) $4 \times 10^{3} \mathrm{~s}^{-1}$; (e) $5 \times 10^{3} \mathrm{~s}^{-1} \mathrm{Ni}_{63} \mathrm{Al}_{32} \mathrm{Cu}_{6} ;$ (f) $5 \times 10^{3} \mathrm{~s}^{-1} \mathrm{Ni}_{63} \mathrm{Al}_{32} \mathrm{Cu}_{7}$.

\section{Conclusions}

The impact flow response of $\mathrm{NiAl}$ intermetallic alloy with $\mathrm{Cu}$ contents ranging from 5 to 7 at $\%$ has been investigated under room temperature conditions at strain rates in the range of $10^{-3}-5 \times 10^{3} \mathrm{~s}^{-1}$. It has been shown that the flow stress, strain rate sensitivity, hardness and ductility of the NiAl alloy all increase with an increasing $\mathrm{Cu}$ content. The microstructural observations have revealed that the change in the mechanical flow response of the NiAl alloy with an increasing $\mathrm{Cu}$ addition is the result of the increased precipitation of $\gamma^{\prime}$-phase $(\mathrm{Ni}, \mathrm{Cu})_{3} \mathrm{Al}$ from $\beta$-phase $(\mathrm{Ni}, \mathrm{Cu}) \mathrm{Al}$ in the NiAl matrix.

Acknowledgments: The authors gratefully acknowledge the financial support provided to this study by the National Science Council (NSC) of Taiwan under Contract No. NSC 102-2221-E-151-006-MY3.

Author Contributions: Tao-Hsing Chen was involved in writing and designing the aim of this manuscript. Jian-Hong $\mathrm{Wu}$ did the experiment. Tao-Hsing Chen conceived the scope of the paper. Tao-Hsing Chen discussed the conclusions, reviewed the manuscript and reply to the reviewer's comment.

Conflicts of Interest: The authors declare no conflict of interest. 


\section{References}

1. Miracle, D.B. Overview No. 104. The physical and mechanical properties of NiAl. Acta Metall. Mater. 1993, 41, 649-684. [CrossRef]

2. Zhao, H.L.; Qiu, F.; Jin, S.B.; Jiang, Q.C. High work-hardening effect of the pure NiAl intermetallic compound fabricated by the combustion synthesis and hot pressing technique. Mater. Lett. 2011, 65, 2604-2606. [CrossRef]

3. Ozdemir, O.; Zeytin, S.; Bindal, C. Characterization of NiAl with cobalt produced by combustion synthesis. J. Alloys Compd. 2010, 508, 216-221. [CrossRef]

4. Noebe, R.D.; Bowman, R.R.; Nathal, M.V. Physical and mechanical properties of the B2 compound NiAl. Int. Mater. Rev. 1993, 38, 193-232. [CrossRef]

5. Liu, E.; Jia, J.; Bai, Y.; Wang, W.; Gao, Y. Study on preparation and mechanical property of nanocrystalline NiAl intermetallic. Mater. Des. 2014, 53, 596-601. [CrossRef]

6. Zhou, Y.J.; Zhang, Y.; Wang, Y.L.; Chen, G.L. Solid solution alloys of $\mathrm{AlCoCrFeNiTi}_{x}$ with excellent room-temperature mechanical properties. Appl. Phys. Lett. 2007, 90, 181904-1-181904-3. [CrossRef]

7. Zhu, J.M.; Fu, H.M.; Zhang, H.F.; Wang, A.M.; Li, H.; Hu, Z.Q. Microstructures and compressive properties of multicomponent AlCoCrFeNiMo $x$ alloys. Mater. Sci. Eng. A 2010, 527, 6975-6979. [CrossRef]

8. Chuang, M.H.; Tsai, M.H.; Wang, W.R.; Lin, S.J.; Yeh, J.W. Microstructure and wear behavior of $\mathrm{Al}_{x} \mathrm{Co}_{1.5} \mathrm{CrFeNi}_{1.5} \mathrm{Ti}_{y}$ high-entropy alloys. Acta Mater. 2011, 59, 6308-6317. [CrossRef]

9. Lee, J.W.; Hyun, S.K.; Kim, M.S.; Kim, M.G.; Ide, T.; Nakajima, H. Ductility improvement of intermetallic compound NiAl by unidirectional pores. Mater. Lett. 2012, 74, 213-216. [CrossRef]

10. Stephens, J.R. High Temperature Ordered Intermetallic Alloys. In Proceedings of the MRS Symp., Boston, MA, USA, 26 November 1985; Koch, C.C., Liu, C.T., Stoloff, N.S., Eds.; Materials Research Society: Warrendale, PA, USA, 1985; Volume 39, p. 381.

11. Sheng, L.Y.; Guo, J.T.; Ye, H.Q. Microstructure and mechanical properties of NiAl-Cr(Mo)/Nb eutectic alloy prepared by injection-casting. Mater. Des. 2009, 30,964-969. [CrossRef]

12. Ferrandini, P.; Batista, W.W.; Caram, R. Influence of growth rate on the microstructure and mechanical behaviour of a NiAl-Mo eutectic alloy. J. Alloy. Compd. 2004, 381, 91-98. [CrossRef]

13. Ishida, K.; Kainuma, R.; Ueno, N.; Nishizawa, T. Ductility enhancement in NiAl (B2)-base alloys by microstructural control. Metall. Trans. A 1991, 22A, 441-446. [CrossRef]

14. Colín, J.; Serna, S.; Campillo, B.; Flores, O.; Juárez-Islas, J. Microstructural and lattice parameter study of as-cast and rapidly solidified $\mathrm{NiAl}$ intermetallic alloys with $\mathrm{Cu}$ additions. Intermetallics 2008, 16, 847-853. [CrossRef]

15. Zhou, W.L.; Guo, J.T.; Chen, R.S.; Li, G.S.; Zhou, J.Y. Superplasticity in NiAl intermetallics macroalloyed with iron. Mater. Lett. 2001, 47, 30-34. [CrossRef]

16. Duman, N.; Mekhrabov, A.O.; Akdeniz, M.V. Microalloying effects on the microstructure and kinetics of nanoscale precipitation in NiAlFe alloy. Intermetallics 2012, 23, 217-227. [CrossRef]

17. Sheng, L.; Zhang, W.; Guo, J.; Yang, F.; Liang, Y.; Ye, H. Effect of Au addition on the microstructure and mechanical properties of NiAl intermetallic compound. Intermetallics 2010, 18, 740-744. [CrossRef]

18. Jeon, S.J.; Lee, H.C. Effect of copper alloying on the deformation behavior of B2 NiA1 intermetallic compounds. Mater. Sci. Eng. A 1992, 153, 392-397. [CrossRef]

19. Colin, J.; Gonzalez, C.; Herrera, R.; Juarez-Islas, J.A. Analysis of chill-cast NiAl intermetallic compound with copper additions. J. Mater. Eng. Perform. 2002, 11, 487-491. [CrossRef]

20. Kainuma, R.; Imano, S.; Otani, H.; Ishida, K. Microstructural evolution in ductile B(B2) $+\gamma^{\prime}\left(\mathrm{L1}_{2}\right) \mathrm{Ni}-\mathrm{Al}-\mathrm{Fe}$ alloys. Intermetallics 1996, 4, 37-45. [CrossRef]

21. Noebe, R.D.; Cullers, C.L.; Bowman, R.R. The effect of strain rate and temperature on the tensile properties of NiAl. J. Mater. Res. 1992, 7, 605-612. [CrossRef]

22. Moskovic, R. Mechanical properties of precipitation-strengthened Ni-Al-Cr alloy based on an $\mathrm{NiAl}$ intermetallic compound. J. Mater. Sci. 1978, 13, 1901-1906. [CrossRef]

23. Busso, E.P.; McClintock, F.A. A dislocation mechanics-based crystallographic model of a B2-type intermetallic alloy. Inter. J. Plast. 1996, 12, 1-28. [CrossRef]

24. Wright, T.W.; Batra, R.C. The initiation and growth of adiabatic shear bands. Inter. J. Plast. 1985, 1, $205-212$. [CrossRef] 
25. Marchand, A.; Duffy, J. An experimental study of the formation process of adiabatic shear bands in a structural steel. J. Mech. Phys. Solids 1988, 36, 251-283. [CrossRef]

26. Lee, W.S.; Liu, C.Y.; Chen, T.H. Adiabatic shearing behavior of different steels under extreme high shear loading. J. Nucl. Mater. 2008, 374, 313-319. [CrossRef]

27. Philpot, K.A.; Munir, Z.A.; Holt, J.B. An investigation of the synthesis of nickel aluminides through gasless combustion. J. Mater. Sci. 1987, 22, 159-169. [CrossRef]

28. Liu, C.T.; Stiegler, J.Q. ASM Handbook; ASM International: Novelty, OH, USA, 1990; Volume 11, p. 919.

29. Egg, S.S.; Sue, Y.Q.; Hirsch, P.B. Strain rate dependence of the flow stress and work hardening of $\gamma^{\prime}$. Mater. Sci. Eng. A 1995, 192-193, 45-52.

30. Lee, W.S.; Chen, C.W. Dynamic mechanical properties and microstructure of Ti-6Al-7Nb biomedical alloy as function of strain rate. Mater. Sci. Technol. 2013, 9, 1055-1064. [CrossRef]

31. Chen, T.H.; Hsu, Y.K.; Fang, T.E. The deformational behaviour and microstructural evolution of Al-Sc-Zr alloys with different copper content under high strain rate impact loading. J. Chin. Soc. Mech. Eng. 2014, 35, 499-506.

32. Lee, W.S.; Lin, C.F. High-temperature deformation behaviour of Ti6Al4V alloy evaluated by high strain-rate compression tests. J. Mater. Process. Technol. 1998, 75, 127-136. [CrossRef]

(C) 2016 by the authors; licensee MDPI, Basel, Switzerland. This article is an open access article distributed under the terms and conditions of the Creative Commons by Attribution (CC-BY) license (http:/ / creativecommons.org/licenses/by/4.0/). 